\title{
The Application of Geographic Information System for Mapping Superior Food Commodities in Tabanan Regency
}

\author{
Ni Kadek Oki Febrianti \\ Agroecotechnology Department, \\ Agriculture Faculty, University of Udayana \\ Denpasar, Indonesia \\ Corresponding email: kadekokifebrian@gmail.com \\ Tati Budi Kusmiyarti \\ Agroecotechnology Department, \\ Agriculture Faculty, University of Udayana \\ Denpasar, Indonesia \\ I Ketut Sardiana \\ Agroecotechnology Department, \\ Agriculture Faculty, University of Udayana \\ Denpasar, Indonesia
}

\begin{abstract}
Tabanan regency well knowns as central food commodities in Bali province. This regency cultivate food commodities such as rice, corn, cassava, sweet potato, soybean, red bean, green pea, and peanut. The study aims to know superior food commodities in Tabanan regency. The set of evaluation used by district area with secondary data of total production food commodities in 2009-2014. Geographic information system used to analysis spatial data, whereas the superior food commodities used location quotient method (LQ). The result showed there are six food commodities in Tabanan regency consists of rice, corn, cassava, sweet potato, soybean, and peanut. Rice as superior commodity in sub-district Penebel with LQ value 1,01, Pupuan 1,01, Selemadeg 1,01 and West Selemadeg 1,01. Corn commodity as superior in sub-district East Selemadeg 7,38, Kerambitan 2,54 and Tabanan 1,13. Cassava commodity as superior in sub-district Kediri 13,59, Marga 6,2 and Baturiti 3,08. Sweet potato commodity as superior in sub-district Baturiti 37,31, Kediri 3,72 and Pupuan 2,31. Soybean commodity superior in sub-district Tabanan 12,63, Marga 8,52 and Kediri 6,15. Peanut commodity as superior in sub-district Baturiti 43,17 and Pupuan 4,35.
\end{abstract}

Keywords-Food, commodity, superior, GIS, LQ

\section{INTRODUCTION}

Indonesia's population growth rate is estimated to reach 220 million in 2020 and is projected to be 270 million in 2025 . Food is a necessity that must be provided in a sufficient amount, safe and nutritious in a sustainable manner. Food consumption in Indonesia is quite diverse, including rice, maize, cassava, sweet potatoes, peanuts, soya beans and green beans. Tabanan regency is very likely to be developed as a regional food provider in the province of Bali. Tabanan regency is able to produce as much as 233681 tons of paddy rice or supplied $26.53 \%$ of the total amount of rice in the province of Bali (BPS Provinsi Bali, 2014).

In addition to having the high potential to produce enough rice commodities, Tabanan also has the potential to develop food commodities besides rice, maize, cassava, sweet potatoes, soybeans, and peanuts. The existence of this potential development is not known for sure yet, therefore it is necessary to conduct analysis which is then mapped in order to be more easily understood.

The method of analysis of location quotient (LQ) is used to determine whether or not a commodity excels in an area. This study aims to determine the potency and the existence of any superior food commodity in the respective sub-districts in Tabanan Regency.

\section{METHOD}

\section{A. Time and Place Research}

The research is conducted in February 2015 until April 2015, starting from the stage of preparation, data collection, data processing and mapping the superior food commodity in Tabanan. This research is conducted in the GIS Laboratory of Soil and Environmental Science Concentration, Agroecotechnology Department, Faculty of Agriculture, University of Udayana, in which the study area is taken place in Tabanan.

\section{B. Materials and Equipment}

The materials used in this study is data on average of planting area, production area, harvested area and production 
of food crops in Tabanan sub-district from 2009 to 2014 (BPS Tabanan Regency Year 2009 to 2014). Other supporting data is in the form of data on land characteristics of each sub-subdistrict in Tabanan regency, as well as data on land characteristic suitable for some food commodities. Other things required are a supporting map in the form of administrative boundary maps, land use maps, and other supporting maps if needed. The tools used in this study includes a set of computers, software QGIS 2.16 used in the creation of superior commodity maps and Microsoft Excel for data calculation and printer.

\section{Procedure / Phases Research}

- Data collection

Data needed in this research is secondary data collected from various sources. The data obtained are then processed to obtain the desired data.

- Data analysis

Data analysis was conducted on Ms. Excel 2013 which includes data insertion and calculation of the average secondary data that has been obtained previously. The analyzed data is the average value of production of each commodity. Results of the average was notated "pi", then the average value of each commodity in each region was summed (sum vertical) according to each subsector notated "pt". After the data of average obtained, the data was then summed. The value of production in different spreadsheets was summed; this sum yielded total of production, and the area of each region notated with "Pi", then the whole sum was summed up on all food commodities from all regions then notated "Pt".

In simpler calculation according to Hendayana LQ. R (2003) can be formulated as follows:

$$
L Q=\frac{p i / p t}{P_{i} / P t}
$$

pi = Production of commodities ' $i$ ' at the sub-district level

pt $=$ Total production of the commodity groups at the subdistrict level

$\mathrm{Pi}=$ Production of commodities ' $i$ ' at the regency level

$\mathrm{Pt}=$ Total production of the commodity groups at the regency level

Criteria:

LQ>1: Superior sector means commodity $\mathrm{i}$ in a region has a comparative superiority

$\mathrm{LQ}=1$ : Not superior sector, which means that commodity $\mathrm{i}$ in a region does not Have the superiority, production is only sufficient to meet the needs of its own territory

$\mathrm{LQ}<1$ : Not superior sector, which means that commodity $i$ in a region cannot meet its own needs that need supplies from outside

Explanation: The higher the LQ sector value in a region, the higher the superior potency of the sector.

\section{Unit Creation Research Areas}

- Spatial data collection in the form of a map of Tabanan regency administration is scanned and then formatted into JPEG.

- Making the unit area of research (mapping unit).

1) Registration map

2) Digitized maps

3) Table and labeling

4) Matching data or match data between spatial data LQ analysis layout of a direction map of superior food commodities development.

\section{FINDING AND DISCUSSION}

Superior food commodities with the value of $\mathrm{LQ}>1$ are presented in Table 1, next for the distribution map in each subdistrict is presented in Table Figure 1. The attributes of each polygon based on superior commodities can be described as follows:

\section{A. Food Commodities Commodity According to the Sub- district in Tabanan}

Based on the analysis described in Tables 1 and 2, there are six food commodities cultivated in ten sub-districts in Tabanan. Each of these food commodities has a diverse LQ. It is described in more detail below:

\section{- Rice Commodity}

Based on the analysis of crop production LQ in Tabanan, rice plants cultivated in ten sub-districts but not all become superior places for paddy. Rice Commodity becomes superior commodity (LQ> 1) in four sub-subdistricts: Penebel (1.01), Pupuan (1.01), Selemadeg (1.01), and West Selemadeg (1.01). Other sub-districts that are not superior rice area (LQ<1) are Baturiti (0.92), Kediri (0.97), Kerambitan (0.99), Marga (0.99), East Selemadeg (0.95) and Tabanan (0.99) (Table 1).

Based on data obtained from BPS Tabanan regency in 2009-2014 (Table 1), it is shown that the average number of the highest production in the Sub-district Penebel shown as much 357,477.72 tons/year, followed by the Sub-district Kerambitan much as 205,133.90 tons/year. Penebel Subdistrict supplies $49.61 \%$ of the total average production in Tabanan and Sub-district Kerambitan supplies $28.47 \%$.

Sub-district of Selemadeg and West Selemadeg has a value LQ>1 meanwhile if viewed from the amount of production only is only 17554.60 ton/year and 17477.56 tons/year respectively.

LQ> 1 in the sub-district is because these two subdistricts only cultivate paddy alone. LQ comparative calculated values in this study is only analyzed on food commodities, so it needs further research on other commodities such as horticulture and plantations so that the results are more accurate. Paddy land area in Penebel Sub- 
district of 8,248 Ha. This situation is not the largest area in Tabanan. The largest area is in Kerambitan Sub-district with an area of $9445.33 \mathrm{Ha}$. Penebel Sub-district is able to produce paddy commodity higher than the Kerambitan Sub-district despite a lower crop area.

\section{- Corn Commodity}

Based on the result of the analysis LQ of crop production in Tabanan, corn plants are cultivated in seven sub-districts and become the leading commodity in the Sub-sub-district Kerambitan (2.55), East Selemadeg (7.38) and Tabanan (1.14). Other sub-districts that are not a superior corn areas are sub-district of Kediri (0.09), Marga (0.29), Penebel (0.01) and Pupuan (0.11).

Total average production of maize can be seen in Table 1. The highest production in Sub Kerambitan supplies as many 3936.48 tons/year or $72.8 \%$, Sub-district East Selemadeg produces as much as 1155.94 tons/year or supplies $21.38 \%$, Tabanan Sub-district produces as much as 184.6 tons/year or $3.41 \%$ of the total supply of maize production in Tabanan (BPS Tabanan, 2009-2014).
The largest maize area in the Sub-district Kerambitan is $394.38 \mathrm{Ha}$, followed by the Sub-district Selemadeg Eastern Sub-district of Tabanan $225 \mathrm{Ha}$ and 26.6 Ha. Particularly in Baturiti Sub-district, corn production value is 0 for cultivated corn is harvested when still young, while for corn used as food ingredients must be Harvested old/dry.

The diversity of commodities in the Sub-district Kerambitan, East Selemadeg, and Tabanan equally cultivate three food commodities but the production value of food commodities in the Sub-district Kerambitan almost all high that the value of the denominator becomes higher. The high divider value results in a maize LQ value in Subdistrict Kerambitan less than 1. In contrast to the Subdistrict of East Selemadeg, although equally cultivate three food commodities, but only the value of corn production is likely to dominate, that is the second highest production with maize value of LQ yielded is more than one.

TABLE 1. NUMBER OF AVERAGE PRODUCTION (TON) FOOD COMMODITIES IN TABANAN

\begin{tabular}{|c|c|c|c|c|c|c|c|c|}
\hline No & $\begin{array}{c}\text { Sub- } \\
\text { district/Com } \\
\text { modity }\end{array}$ & Rice & Corn & Cassava & $\begin{array}{l}\text { Sweet } \\
\text { Potato }\end{array}$ & Soybean & Peanut & Total \\
\hline 1 & Baturiti & 14099.30 & ${ }^{*} 0.00$ & 100.48 & 1253.54 & 0.00 & 120.90 & 15574.22 \\
\hline 2 & Kediri & 32373.67 & 21.58 & 793.51 & 271.56 & 211.82 & 2.56 & 33674.70 \\
\hline 3 & Kerambitan & 205133.90 & 3936.48 & 0.00 & 0 & 14.40 & 0.00 & 209084.78 \\
\hline 4 & Marga & 25057.91 & 55.25 & 333.00 & 0 & 222.67 & 0.00 & 25668.83 \\
\hline 5 & Penebel & 357477.72 & 45.38 & 132.20 & 0 & 0.00 & 0.00 & 357655.30 \\
\hline 6 & Pupuan & 9891.79 & 8.18 & 0.00 & 49.52 & 0.00 & 7.79 & 9957.28 \\
\hline 7 & Selemadeg & 17554.60 & 0.00 & 0.00 & 0 & 0.00 & 0.00 & 17554.60 \\
\hline 8 & $\begin{array}{c}\text { West } \\
\text { Selemadeg }\end{array}$ & 17477.56 & 0.00 & 0.00 & 0 & 0.00 & 0.00 & 17477.56 \\
\hline 9 & $\begin{array}{c}\text { East } \\
\text { Selemadeg }\end{array}$ & 19962.86 & 1155.94 & 0.00 & 0 & 11.88 & 0.00 & 21130.68 \\
\hline 10 & Tabanan & 21505.10 & 184.60 & 0.00 & 0 & 282.66 & 0.00 & 21972.36 \\
\hline & Total (S) & 720534.42 & 5407.41 & 1359.19 & 1574.62 & 743.43 & 131.25 & 729750.31 \\
\hline
\end{tabular}

Source: Data processed by author from Badan Pusat Statistik Tabanan Regency Year 2009-2014

\section{- Cassava Commodity}

Based on the analysis of crop production LQ in Tabanan, cassava plants are cultivated in four sub-districts and become a superior commodity in the sub-district
Baturiti (3.02), Kediri (13.25) and Marga (6.07). The other sub-district that is not superior area of not cassava is Penebel Sub-district (0.22).

The highest average amount of cassava production is in the sub-district of Kediri with production as much as 
962.81 tons/year or supplies $62.99 \%$ of the entire cassava production in Tabanan.

Furthermore, the Sub-district of Marga produces 333 ton/Ha or supplies $21.79 \%$, Penebel 132.20 ton/Ha or $8.65 \%$ and the last in Baturiti supplies as much as 100.48 tons/year or supply as much as $6.57 \%$ (Table 1 ).

According to the Harvest area, the highest area is in Sub-district Baturiti area which is of $52.60 \mathrm{Ha}$, followed by the Sub-district Marga $13.60 \mathrm{Ha}$, sub-district of Kediri 12.33 Ha, Last Penebel Sub-district Ha and 4.40 Ha (BPS Tabanan, 2009-2014).

The diversity of food commodities in each sub-district is quite varied. Sub-district Baturiti cultivates four food commodities, sub-district of Kediri six food commodities, Sub-district Marga cultivated four food commodities, and Sub-district Penebel cultivates three food commodities. Despite the diversity of food commodities in the Subdistrict of Kediri, the only commodity more dominated that the other sub-districts in Tabanan Regency is corn, making its LQ value more than 1 .

- Sweet Potatoes Commodity

Based on the analysis LQ crop production in Tabanan, sweet potato crops are cultivated in the three sub-districts, all of which featured local sweet potato commodities. These Sub-districts are the Sub-district Baturiti (37.32), Kediri (3.71) and Pupuan (2,31).

Based on BPS data of Tabanan regency in 2009-2014, the average amount of production is highest in Baturiti is as much as 1253.54 tons/year or $79.61 \%$ of the total supply amount of sweet potato production in Tabanan.
Furthermore, sub-district of Kediri produces as much as 271.56 tons/Ha or $17.25 \%$ and the last, the Sub-district of Pupuan as much as 49.52 tons/Ha or supplies $3.14 \%$. The area of sweet potato Harvest was highest in Baturiti of 75 Ha, followed by the Sub-district Pupuan of $11.60 \mathrm{Ha}$ and the last Sub-district of Kediri by $3 \mathrm{Ha}$.

- Soybean Commodity

Based on the LQ analysis of crop production in Tabanan, soybean plants cultivated in five sub-districts and becomes the leading commodity in the cassava production in Tabanan. Furthermore, Sub-district of Marga produce as much as 222.67 tons/year (29.95\%), and the sub-district of Kediri as much as 211.82 tons/year (28.49) (BPS Tabanan, 2009-2014)

The area of the largest Harvest in the sub-district of Kediri contained in the amount of $423.33 \mathrm{Ha}$, followed by 202.06 Ha for Sub-district of Tabanan, Sub-district Marga is $146 \mathrm{Ha}$, Sub-district East Selemadeg of $15.80 \mathrm{Ha}$ and the last Sub-district Kerambitan $12 \mathrm{Ha}$.

The value of soybean production in the sub-district of Tabanan tend to dominate when compared with the value of soybean production in other sub-districts in Tabanan. It is very possible for a commodity to be a superior commodity for its high production values and dominating tendency.

TABLE 2. LQ VALUE OF FOOD COMMODITY PR6ODUCTION PER SUB-DISTRICT IN TABANAN REGENCY

\begin{tabular}{llllllll}
\hline No & $\begin{array}{c}\text { Sub- } \\
\text { district/Commodity }\end{array}$ & Rice & Corn & Cassava & $\begin{array}{l}\text { Sweet } \\
\text { Potato }\end{array}$ & Soybean & Peanut \\
\hline $\mathbf{1}$ & Baturiti & 0.92 & 0.00 & 3.08 & 37.31 & 0.00 & 43.17 \\
\hline $\mathbf{2}$ & Kediri & 0.97 & 0.09 & 13.59 & 3.72 & 6.15 & 0.42 \\
\hline $\mathbf{3}$ & Kerambitan & 0.99 & 2.54 & 0.00 & 0.00 & 0.07 & 0.00 \\
\hline $\mathbf{4}$ & Marga & 0.99 & 0.29 & 6.20 & 0.00 & 8.52 & 0.00 \\
\hline $\mathbf{5}$ & Penebel & 1.01 & 0.02 & 0.18 & 0.00 & 0.00 & 0.00 \\
\hline $\mathbf{6}$ & Pupuan & 1.01 & 0.11 & 0.00 & 2.31 & 0.00 & 4.35 \\
\hline $\mathbf{7}$ & Selemadeg & 1.01 & 0.00 & 0.00 & 0.00 & 0.00 & 0.00 \\
\hline $\mathbf{8}$ & West Selemadeg & 1.01 & 0.00 & 0.00 & 0.00 & 0.00 & 0.00 \\
\hline $\mathbf{9}$ & East Selemadeg & 0.96 & 7.38 & 0.00 & 0.00 & 0.55 & 0.00 \\
\hline $\mathbf{1 0}$ & Tabanan & 0.99 & 1.13 & 0.00 & 0.00 & 12.63 & 0.00 \\
\hline
\end{tabular}




\section{- Peanut Commodity}

Based on the LQ analysis of crop production in Tabanan, peanut plants are cultivated in three sub-districts, namely in Sub-district of Baturiti (43.17), Sub-district of Pupuan (4.35) and the sub-district of Kediri (0.42), but not all of them are superior area for peanut commodity. Peanut commodities become the leading commodity (LQ>1) in the two sub-districts which is in Sub-district Baturiti (43.17), and Pupuan (4.35).

Data obtained from BPS Tabanan regency in 2009-2014 showed that the average number of the highest production of peanuts in Baturiti is as much as 120.90 tons/year or $92.11 \%$ of the total supply amount of peanut production in Tabanan. Sub-district of Pupuan followed as much as 7.79 tonnes/year or supplies $5.93 \%$. The area of peanut commodity cultivation in Baturiti is the highest area in Tabanan, namely $20.20 \mathrm{Ha}$, followed by the Sub-district Pupuan of $5.99 \mathrm{Ha}$.

\section{B. Priority Development Management of Superior Food Commodities in Each Sub-district in Tabanan Regency}

Referring to the discussion on the leading commodity in each sub-district, it is known that the distribution of food commodities is featured in all sub-districts in Tabanan. The distribution of these commodities is based on the LQ value of superior commodities (LQ>1) from each of the food commodities, food commodities has a value of $L Q>1$ at a subsub-district will become a reference on the priority development of food commodities in these sub-districts.

Based on the analysis of Location Quotient (LQ) on some food commodities in Tabanan show that superior rice commodity is spread in four sub-sub-districts, namely Penebel (1.01), Pupuan (1.01), Selemadeg (1.01) and West Selemadeg (1.01). Priority development of paddy in Tabanan is developed in Sub-district of Penebel and Pupuan. In the Sub-district of Selemadeg and West Selemadeg need to do further analysis, given the results of the evaluation of the suitability of the land to paddy ranged between S3-rn to N2-s, with the limiting factor effective depth (r), the availability of nutrients (n), and slope (s) (Sardiana, et al, 2015). Total average production of paddy in each of these sub-districts is the Sub-district Penebel produces as much 357.477.72 tons/year, followed by the Subdistrict of Selemadeg 17554.60 ton/year, West Selemadeg 17477.56 ton/year and last sub-district of Pupuan 9891, 79 tons/year. The area of paddy Harvest in each of these subdistricts, namely the Sub-district of Penebel is $8,248 \mathrm{Ha}$, Subdistrict of Pupuan is $1847.8 \mathrm{Ha}$, Sub-district of Selemadeg 3536, 2 West Selemadeg 2312.4 Ha. Map of the distribution area of paddy commodity can be seen in Figure 1.

Sub-districts that become superior corn area is spread across three sub-sub-districts, namely Kerambitan (2.55), East Selemadeg (7.38) and Tabanan (1.14). Total average production of corn that is counted in the Sub-district Kerambitan as many 3936.48 tons/year, Sub-district of East
Selemadeg produces as much as 1155.94 tons/year, and the last Sub-district of Tabanan produce as much as 184.6 tons/year. The area of corn commodity sub-district of Kerambitan is 394.38 Ha, Sub-district East Selemadeg of $225 \mathrm{Ha}$ and $26.6 \mathrm{Ha}$ Sub-district of Tabanan. Map of the distribution of corn commodity region can be seen in Figure 1.Cassava Commodity becomes main commodity in the four sub-districts, namely in Baturiti (3.02), Kediri (13.25) and Marga (6.07). The average amount of cassava production is in the sub-district of Kediri is as much as 793.51 tons/year, Sub-district Marga produce 333 ton/Ha, and the last in Sub-district Baturiti as much as 100.48 tons/year. According to the Harvest area, corn was cultivated in Baturiti for 52,6 Ha, Sub-district Marga amounting to $13.60 \mathrm{Ha}$ and $12.33 \mathrm{Ha}$ for the last, sub-district of Kediri. 4.40 Ha. Commodity distribution maps featured local cassava can be seen in Figure 1.

The distribution area of sweet potato commodities are featured in three sub-sub-districts Baturiti (37.32), Kediri (3.71) and Pupuan (2,31). The average amount of production is highest in Baturiti is as much as 1253.54 tons/year, followed sub-district of Kediri produce as much as 271.56 tons/Ha, and the last Sub-district Pupuan produces as much as 49.52 tons/Ha. The area of sweet potato Harvest is highest in Baturiti of $75 \mathrm{Ha}$, followed by the Sub-district Pupuan of $11.60 \mathrm{Ha}$ and the last sub-district of Kediri by $3 \mathrm{Ha}$. Commodity distribution maps featured deaerah sweet potato can be seen in Figure 1.

Soybean commodity superior area is spread over three subdistricts, namely in the sub-district of Tabanan (12.63), Subdistrict of Marga (8.52), and in the sub-district of Kediri (6.12). The average amount of soybean production in the subdistrict covers Tabanan much as 282.66 tons/Ha, Sub-district Marga produces as much as 222.67 tons/year, and the subdistrict of Kediri as much as 211.82 tons/year. The area of the largest Harvest in the sub-district of Kediri contained in the amount of $423.33 \mathrm{Ha}$, followed by $202.06 \mathrm{Ha}$ of Sub-district of Tabanan, and Sub-district. Map of the distribution area of soybean seed can be seen in Figure 1 .

Peanut Commodity becomes the leading commodity in Baturiti (43.17), and the Sub-district Pupuan (4.35). The average amount of the highest production of peanuts in Baturiti is as much as 120.90 tons/year, followed Sub-district Pupuan as much as 7.79 tons/year. The area of peanut cultivation, namely Sub-district of Baturiti of $20.20 \mathrm{Ha}$, followed by the Sub-district Pupuan of 5.99 Ha. Commodity distribution maps featured area peanuts can be seen in Figure 1.

\section{CONCLUSIONS AND SUGGESTIONS}

\section{A. Conclusion}

Based on the results of the study at six food commodities in Tabanan can be summarized as follows:

- The superior food commodities in each sub-district consists of: 1) Baturiti three superior food commodities, which are commodities of peanuts, sweet potatoes, and 
cassava; 2) Sub-district of Kediri there are three featured food commodities are commodities cassava, soybean and sweet potato; 3) The Sub-district Kerambitan consists of a food commodity, namely corn commodity; 4) The Sub-district Marga has two superior food commodities namely soybean and cassava; 5) Penebel Sub-district, West Selemadeg, Selemadeg has one superior food commodities namely rice commodities; 6) Sub-district Pupuan has three superior food commodities which are commodities of peanuts, sweet potatoes, and rice; 7) Sub-district of East Selemadeg has a superior food commodities such as corn; 8) Sub-district of Tabanan has two food commodities namely soybean and corn.

- Superior food commodities are scattered in all subdistricts in the regency of Tabanan, such as: 1) Paddy becomes the leading commodity in the Sub-district Penebel, Pupuan, Selemadeg, and West Selemadeg; 2) Corn commodity becomes commodity in Sub-district Kerambitan, Selemadeg East, and Tabanan; 3) Cassava Commodity becomes the leading commodity in Subdistrict Baturiti, Kediri, and Marga: 4) Sweet potato commodity becomes the leading commodity in Subdistrict Baturiti, Kediri, and Pupuan; 5) Soybean commodity becomes the leading commodity in the subdistrict of Kediri, Marga, Tabanan; 6) Peanut Commodities become the leading commodity in the Sub-district Baturiti, and Pupuan.

- Referrals of superior development food commodities in each sub-district include: 1) Rice commodity are developed in the Sub-district Penebel, Selemadeg, West Selemadeg, and Pupuan; 2) Corn commodities are developed in the sub-district of East Selemadeg, Kerambitan, and Tabanan; 3) Cassava commodities are developed in the sub-district of Kediri, Marga, and Baturiti; 4) Sweet potato Commodity developed in Subdistrict Baturiti, Marga, and Pupuan; 5) Soybean commodities are developed in the sub-district of Tabanan, Marga, and Kediri; 6) Peanut commodities were developed in Sub-district Baturiti, and Pupuan.

\section{B. Suggestion}

Based on the results of the mapping study of superior food commodities in Tabanan, data, including amount of production, acreage and Harvested area should be obtained in more details in order the data is not the same from year to year.

\section{REFERENCES}

[1] Badan Pusat Statistik (BPS), "Tabanan Dalam Angka Tahun 20092014. (2009-2014)", Tabanan dalam angka. Tabanan: Author.
[2] Badan Pusat Statistik (BPS) Provinsi Bali, (2014), "Luas Panen, RataRata-Rata Produksi Padi Sawah Provinsi Bali”, Retrieved October 19, 2014, from https://bali.bps.go.id/linkTabelStatis/view/id/26

[3] Hendayana, R 2003, "Aplikasi Metode Location Quotient (LQ) dalam Menentukan Komoditas Unggulan Nasional”, Peneliti Muda, Balai Pengkajian dan Pengembangan Teknologi Pertanian, Bogor

[4] Sardiana, Adhika, \& Sunarta, (2015), "Perencanaan Agroteknopark Kabupaten Tabanan”, BAPPEDA Kabupaten Tabanan:Tabanan. 